Relations industrielles

Industrial Relations

\title{
The Technocrates, Prophets of Automation, by Henry Elsner, Jr., Syracuse University Press, Syracuse, New York, 1967, \$10,00.
}

\section{Benjamin S. Kirsh}

Volume 22, numéro 4, 1967

URI : https://id.erudit.org/iderudit/027853ar

DOI : https://doi.org/10.7202/027853ar

Aller au sommaire du numéro

Éditeur(s)

Département des relations industrielles de l'Université Laval

ISSN

0034-379X (imprimé)

1703-8138 (numérique)

Découvrir la revue

Citer ce compte rendu

Kirsh, B. S. (1967). Compte rendu de [The Technocrates, Prophets of Automation, by Henry Elsner, Jr., Syracuse University Press, Syracuse, New York, 1967, $\$ 10,00$.] Relations industrielles / Industrial Relations, 22(4), 589-589.

https://doi.org/10.7202/027853ar

Tous droits réservés (C) Département des relations industrielles de l'Université Laval, 1967
Ce document est protégé par la loi sur le droit d'auteur. L’utilisation des services d'Érudit (y compris la reproduction) est assujettie à sa politique d'utilisation que vous pouvez consulter en ligne.

https://apropos.erudit.org/fr/usagers/politique-dutilisation/ 
troînement, diminution de la durée du travail, mise à la retraite accélérée, etc.

L'auteur conclue en posant une série de questions auxquelles il répond brièvement. Les unes portent sur ce qu'on peut ou doit ottendre du gouvernement, de l'industrie et des syndicats. Les autres portent sur les responsabilités nouvelles de la communauté, des écoles et des éducateurs.

D'une lecture relativement focile, ce volume offre à tous l'opportunité de se familiariser rapidement avec ces questions brûlontes d'actualité.

\section{André PETIT}

The Technocrates, Prophets of Automation, by Henry Elsner, Jr., Syrocuse University Press, Syracuse, New York, 1967, \$10.00.

During the nineteen thirties, a movement known as technocracy flourished for several years and then, as a comet, moved out of sight. It is recalled now as an episode of the depression years.

Its present importance, however, is its message as prophetic of current discussions of automation.

This volume fills the need of an account of the sources, development and disintegration of technocracy.

It is to be recognized that contures of technocracy, similar to those of automation, cre described with differing limitations by numerous commentators.

Since technocracy was the child of the Great Depression, its emphasis was upon the predominance of the machine, sharp criticisms of the price system, and its high evaluation of engineers, technicians and other scientific personnel.

Its critique of the economic organization was not matched by constructive proposal as - remedy.

The impractal substitution of a standard of value based on energy units to replace the prevalant monetary system led to the disintegration of the technocratic idea, aided by improving economic conditions including the lessening of unemployment.

We are not yet in a position to assess the diverse controversies about either the " good 》 or " evil » consequences of automation. Economic conditions act as impressive guides
Already, the forebodings of the more extreme cassandras with respect to automation's dire effects both present and potential, are being modified. This is true, ot least for the United States, where the Commission on Technology, Automation and Economic Progress found a more favourable economic situation at the end of its investigation, than that which confronted it as the commencement of its work.

Professor Elsner, of the faculty of Villanova University, Pennsylvania, was a been age technocrat, and his participation in its octivities afforded him first hand information of its leading figures, and the complex, often contending organizations which were part of its history.

Of special interest is the valuable bibliography of books, pamphlets, periodicals, and fugitive literature on the subject matter of the book.

For those interested in a phase of the critical attacks and proposed remedies for the price system, and the role of engineers, technicians, and other scientists in our industrial society, this book will shed light on an almost forgotten segment.

\section{Benjamin S. KIRSH}

Challenges to Collective Bargaining, by Lloyd Ulman, Editor, Prentice-Hall, Inc., $\$ 4.95$ clothbound, $\$ 1.95$ Spectrum paperbound, 1967, 192 pages.

This volume contains the papers presented at the American Assembly, at Arden House, the Harriman Campus of Columbia University in October 1966

The scope of the conference may be found in the enumeration of the several subjects under discussion.

After the editor's introduction on the problems in Historic Context, the topics include stability and change in the structure of collective bargaining; pensions, health and welfare plans; collective bargaining in the public sector; the employment and training of minorities; labor relations law; wageprice policy and alternatives; two views of collective bargaining.

Each of chapters is outhored by a leading authority in that particular field. The range of contempary conflicts and problems which the technological age present, not only to management and labor but the public as well, are thoughtfully considered. 